\title{
CHANGES OF ELECTRICAL ACTIVITY OF THE BRAIN DUE TO IRRITATION OF THE TONSIL
}

\author{
By \\ SHIGERU SUGIYAMA \\ From the Department of Oto-Rhino-Laryngology, School of Medicine, \\ Keio University (Director: Prof. Y. Suzuki)
}

Following a surgical maniplation of the pharyngeal area, as in tonsillectomy, development of a shock condition is frequently encountered.

Reilly and others have attributed this particular type of shock to the irritation of the autonomic nerve of that area, through a certain type of reflex mechanism.

The author observed the significant changes of electrical activity of the brain in electroencephalogram after the irritation of the tonsil of the rabbit with Croton Oil.

The changes obtained are spike wave, increased frequency and decreased amplitude.

Such changes of electroencepnalogram, on the other hand were greatly minimized when Chlorpromazine was administered beforehand in the appropriate dose and at the appropriate time.
The results obtained are as follows

1) After injection of Croton Oil to the left tonsil, activating pattern was observed.

2) Activating pattern was observed at the same time in most electrodes.

3) No changes of the electroencephalogram was observed in the rabbit injected with Croton Oil to the abdominal skin.

4) Few changes of electroencephalogram was observed in cases in whicn Chlorpromazine was administered beforehand.

5) Chlorpromazine gave no improvements on the electrical changes produced by the injection of Croton Oil.

6) The higher the activating pattern, the sooner the rabbit died.

\section{家鬼口蓋扁桃の過剩刺激による脳波の変化}

\section{度応義㜪大学耳咽喉科教室（主任：鈴木安恒教授）}

杉㟧繁
$A ：$ 舶 詇

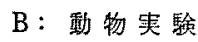
C: 实験成蹟
D：考按及び総括
E：結 部

\section{A：緒 論}

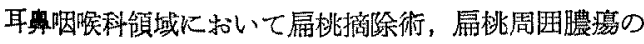
試験穿刺の際など起る急性死の原因として咽頭部の自 律神経の過剩刺激を重視し，我々の教室に打いて多くの 系統的研究かなされている. 従来行われた研究の結果咽 頭部特に扁桃は自律祍経の豊富な場所であり，手術的操 作とよりその部位の末梢自律神経が過剩に刺激され，そ れがショックの発現の何らかの誘因となるのではないか
と考皇られている。過剩刺激が口蓋扁桃の自律神経に与 えられた場合にそれが何らかの経路を通つて中枢に達 し, 中枢から両側性に遠隔部の諸䁍器に急激な出血性病 変をきたすことによりショックが発生するのではないか と云ら考光に立脚し，脳波の变化着目し実験を行つ た。

動物実験には白色家東を使用し，その口蓋扁桃に強い 刺激物であるクロトン油を注射しその前後の脳波に著明 な変化を認め，又自律神経遮断作用のあるクロループロ マシンを使用して脳波の変化の阻止に成功したので発表 する。

\section{B：動 物 実 験}

動物実験には体重 $3 \mathrm{~kg}$ 前後の雄性白色家宫 30 羽を使 
用した．家鬼を使用した理由は次のことくである。

(1) 口蓋叚桃の存在が明確なこと.

(2) 手術的操作を施すことなく比較的簡単に口蓋扁桃 に这射のできること。

(8) 体重 $3 \mathrm{~kg}$ 前後の家鬼の頭蓋骨の大きさの差が少 く，電㰒の刺入に好都合であること.

家鬼の固定には東大脳研式脳固定器を使朋し, 脳実質 内の電極の刺入部位心 Sawyer の脳地図に基づき，㬰 験終了後には組峨学的に電極の刺入位固を確めた。脑奏 質内には直堡 $0.5 \mathrm{~mm}$ のステンレス線の 先端を 鋭利に 研磨し、その先端 $0.5 \mathrm{~mm}$ を残して他の部分は絶緑ラ

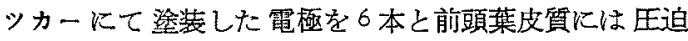
を可及的に少なくする目的で直径 $0.5 \mathrm{~mm}$ の銀球をつ けた螺旋電極を使用した，脳波の記録には日本光電製 ME-131-D 型脳波計を使用した.

電極の位置は

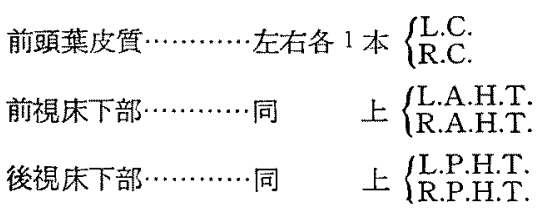

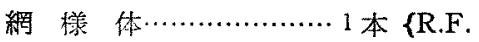

視 林…….............. $\left\{\begin{array}{l}\mathrm{L} . \mathrm{T} . \\ \mathrm{R} . \mathrm{T} .\end{array}\right.$

海 馬....................

家鬼の麻䤃には Nembutal (15〜20 mg/kg) の静派内 投与を行い，脳波上 Nembutal の影響のなくなる1〜2 時間後に脳波を記録した，頭頂部及び前頭骨は最初ドリ ルを使用し次に骨錙子にて出血をさたさないように鉬除

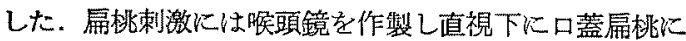
クロトン油原液 $0.2 \sim 0.3 \mathrm{cc}$ 安注射した。

\section{C: 実験成績}

誘導電梄刺入直後の脸波は安定せず, 約 10 分後に比皎的に安定してくる。こ の安定した脳波を約 30 分間記録する。 各誘浖共振门も振動数もほぼ安定し梀波 むほとんどない脳波となる。これを安静 時の脳波之見做した。写真 $A_{1}, B_{1}, C_{1}$, D1のごとくである。

次にクロトン油原液 $(0.2 \sim 0.3 \mathrm{cc})$ を 左䚋の口蓋㦿䄻に注射すると注射時には 脳波は非常に乱れ，注射針を抜くと乞の 直後から各誘導共振動数の増加，振巾の 減少，棘波の著明な出現を見，いわゆる
Activating Pattern と呼ばれる脳波を認めるに至る。 写真 $\mathrm{A}_{2}, \mathrm{~A}_{3}, \mathrm{~B}_{2}, \mathrm{C}_{2}, \mathrm{C}_{3}, \mathrm{C}_{4}$ のごとくである.ク口ト ン油注射後 Activating Pattern の著明なほと実験中の 死亡例が多く60\%が 30 分以内に死亡した. 死亡しない 例では Activating Pattern は20〜30分続き，その後 の脳波は振動数む減少し，振巾も次第に大きくなり，棘 波当ほとえど諗められなくなり，刺激前の脳波に近つい てくる. 死亡例中クロトン油注射の直後に死亡するすの はなく，少くとも15〜30 分は生存した．臨床上見られ るごとき急性死に相当する例には本央験では遭遇しなか つた.

次にクロトン油注射による这波の变化を阻上する目的 で自律神経遮断作用のあるクロールプロマジンを使用し た. その使用量は $5 \mathrm{mg} / \mathrm{kg}$ が最適の効果を示した，即 ら 30 分前にクロールプロマジン $5 \mathrm{mg} / \mathrm{kg}$ を静注してか ら上記の方法で扁桃にクロトン油を注射した例ては異常 梀波の出現は見られず，振動数の增加の著明なすの14 $\%$ ，振巾の減少せるるの 40\%で，クロールプロマジン を使用しないものに比して有意の差が認められた。写真 $\mathrm{D}_{1}, \mathrm{D}_{2}$ のごとくである。

\begin{tabular}{|c|c|c|c|c|}
\hline \multirow{2}{*}{$\begin{array}{l}\text { 家 } \\
\text { 霰 } \\
\text { 数 }\end{array}$} & \multicolumn{4}{|c|}{ クロトン油注射の脳波の変化 } \\
\hline & & $\begin{array}{l}\text { 翼常棘波 } \\
\text { 出現 }\end{array}$ & $\begin{array}{l}\text { 振動数の } \\
\text { 增 斺 }\end{array}$ & $\begin{array}{l}\text { 振 巾の } \\
\text { 少 } \\
\end{array}$ \\
\hline 23 & 焦 処 置 群 & $96 \%$ & $100 \%$ & $83 \%$ \\
\hline 7 & C.P. 使用群 & $0 \%$ & $14 \%$ & $40 \%$ \\
\hline 家鬼数 & \multicolumn{4}{|c|}{ クロトン油注射による死亡率の比較 } \\
\hline 23 & $\begin{array}{l}\text { 無 㚭 璒 } \\
\text { C.P. 使用群 }\end{array}$ & $\begin{array}{l}\text { 以ロトン } \\
\text { 以内の死 }\end{array}$ & 注射後305 & $\begin{array}{r}60 \% \\
0 \%\end{array}$ \\
\hline
\end{tabular}

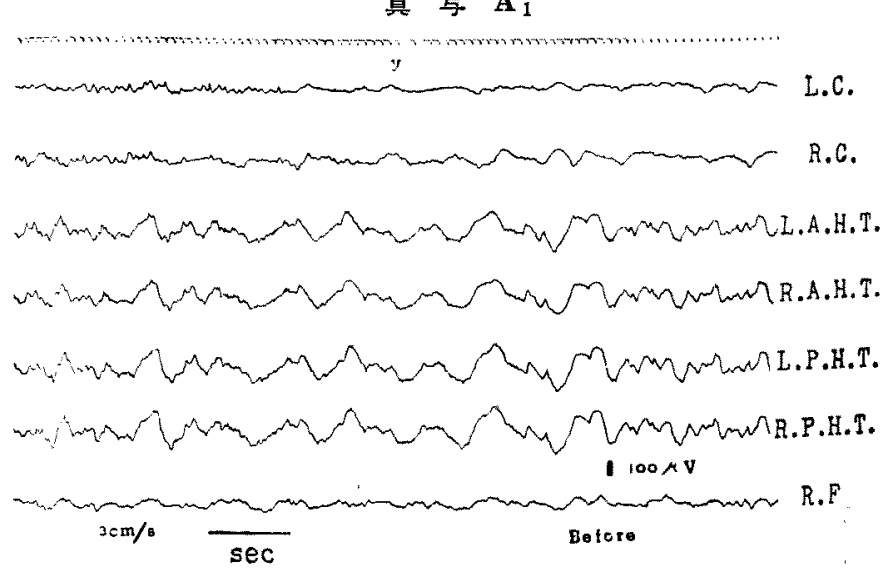


写 真 $\mathbf{A}_{2}$

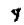

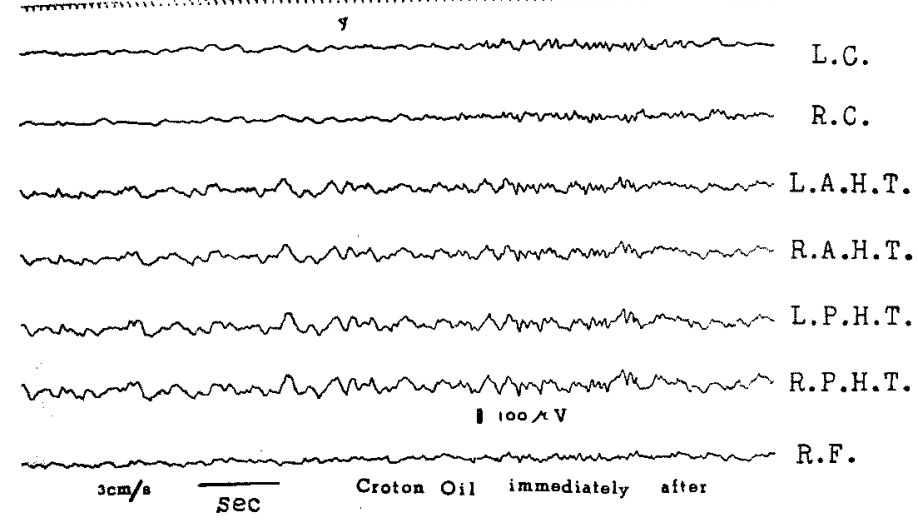

写 真 $\mathbf{A}_{\mathbf{8}}$

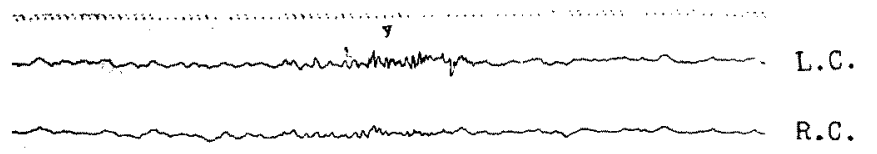

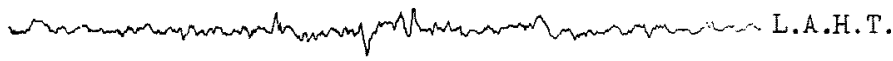

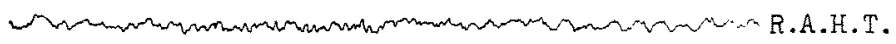

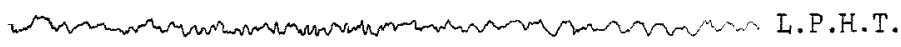

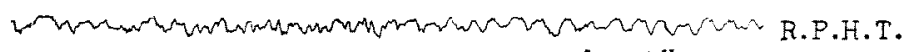

I $100 \times \mathrm{V}$

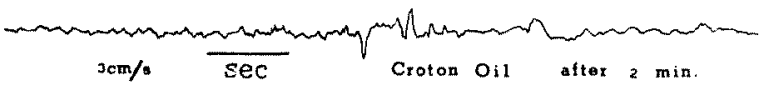

R.F.

\section{写 真 $\mathbf{B}_{\mathbf{1}}$}

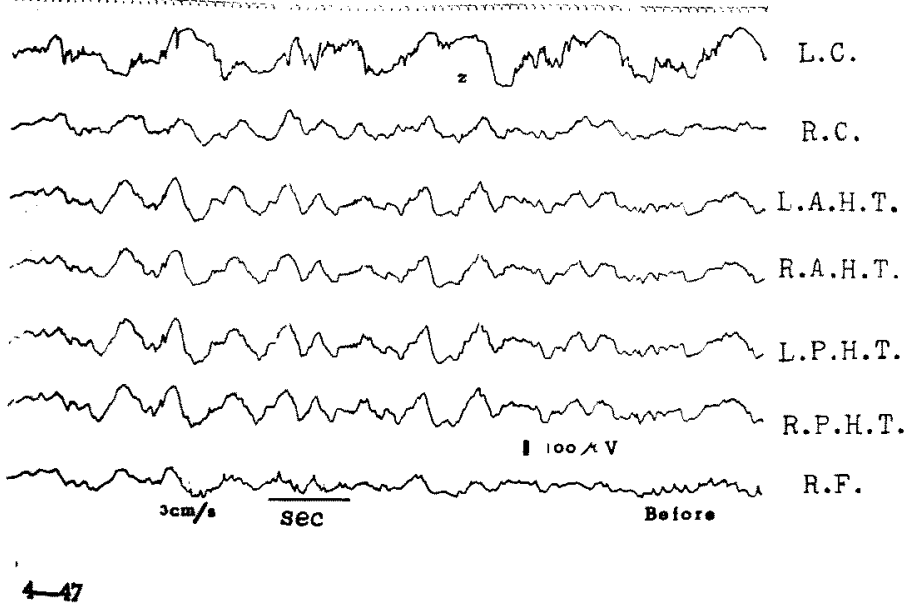

$A_{1}$ は 1 時間前に Nembutal (15 $\mathrm{mg} / \mathrm{kg})$ の静脈内注射を行い電極刺 入後 20 分の脳波で，各誘導共安定 し，䊂波もほとんどなく安静時の脳 波と見なした。

$\mathrm{A}_{2}$ は $\mathrm{A}_{1}$ の家鬼の左側の口蓋局 桃にクロトン油 $(0.3 \mathrm{cc})$ を注射した 直後の脳波で, 振巾の減少, 振動数 の增加と棘波様波型の出現を悲め た。なお 1 側の扁桃を刺激したのに あかかからず,脳波上の変化忙左右 ほぼ同様であり，Activation は週 期性を示す。

$\mathrm{A}_{\mathbf{3}}$ は更に2 分後の脳波であるが， 被刺激側である左の皮質と前視床下 部に著明な变化を認める。この時期 においてる周期性がある.

$B_{1}$ 侍 1 時間前飞 Nembutal (20 $\mathrm{mg} / \mathrm{kg}$ ) を静脈内に注射し電極刺入 後 30 分の安静時の脳波である。

$\mathrm{B}_{2}$ は $\mathrm{B}_{1}$ の家鬼の左側の口蓋局 桃にクロトン油 $(0.2 \mathrm{cc})$ を注射した 直後の脳波で, 著明な振巾の娍少と 振動数の增加を示し，クロトン油注 射後 15 分でショック様应状を呈し 死亡した例である．脳波上の変化で は左右埿は認められない。

$C_{1}$ は 1 時間前に Nembutal (15 $\mathrm{mg} / \mathrm{kg}$ ) 学静脈内に注射乙，電樰剌 入後 20 分の脳波で本実験中最す安 定した脳波である。

$\mathrm{C}_{2}$ は $\mathrm{C}_{1}$ の家鬼の左侧の口蓋扁 桃にクロトン油 $(0.2 \mathrm{cc})$ を注射した 直後の脳波で周期性のある Activationを藷明に認める。左在差侄認 めら机な。

$\mathrm{C}_{3}$ は $\mathrm{C}_{2}$ の振巾の減少してきた むのであるが周期性は存絸する。

$\mathrm{C}_{4}$ は Activation はな括存続する がその周期は延長し振门も回復して 大きくなり，安静時の脳波に近つい てくる.

$\mathrm{D}_{1}$ は 30 分前にクロールブロマシ 


\section{写真 $\mathbf{B}_{2}$}

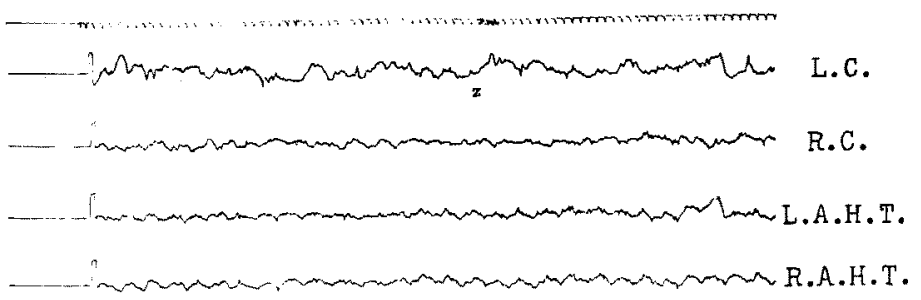

写 真 $\mathbf{C}_{1}$

\section{写 真 $C^{2}$}

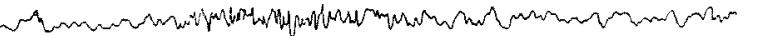

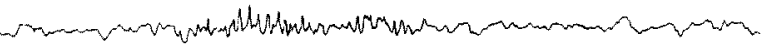

R.C.

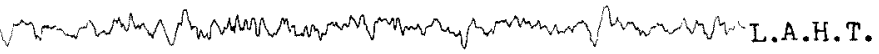

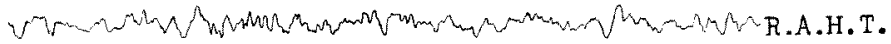

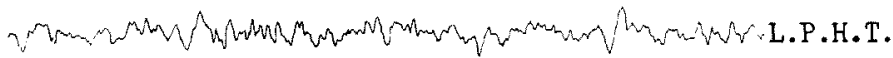

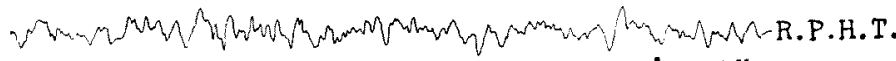

$1100 \mu \mathrm{V}$

3cm/s $\frac{1}{S e C}$ immediately after
ン $(5 \mathrm{mg} / \mathrm{kg})$ を投与したすので安 静時の脳波である.

$\mathrm{D}_{2}$ は $\mathrm{D}_{1}$ の家龟の口盍扁桃炑 ロトン油 (0.3cc) を注射して 2 分後 の脳波であるが，振巾，振動数及び 刺波様波型に関してもほとんど变化 なく，クロールプロマシンが这波の 変化を阻止した例である。

\section{D：考按及び總括}

Reilly は自律神経が過剩に刺激 された場合に遠隔部の諸䁍器に病変 を起すことを Reilly 現象と呼んで いる．我々の教室ではこの現象を重 視し屚桃摘除時等の急性死は，㩔桃 及びその附近の自律神経の䢔剩刺激 が原因となり得ると考光秝机的研究 がなされている，自律神経の存在が 豊富であればあるほど Reilly 現象 が起り易いと考光られ，この点につ いて, 涾瀬 ${ }^{17}$ は人の扁桃の組織学 的研究に执いて詳細な報告をしてい る。これによれば，人の扁桃の上皮 下の固有層には知覚神経終末が少な いが，扁䄻被膜特に雨口蓋弓移行部 に比較的多くの単純性及び複雑性分 忮性終末を認め, 又非分诐性終末磁 飞単純性系㲑状終末を認めており， 植物神経法屚桃の位琶的関係の主要 性を意味するためか非常に豊富に讙 められ，血管壁と所々に神経珄吻合 を示しつつ広範に分布し，いわゆる 植物神経終絧を形成し，特汇神緼原 楾維か゚リンパ小節の周用から求心性 に芽中心に進入し故射線状にリンハ 小節に分布すると述へている.

又松村は家鬼の㫘桃で永瀬と同様 の検索を行い，植物神経の费富な存 在を認めている。

これらの自律神経の存在から厥林 摘除術の際に扁桃の自律神経が遗林 に刺激され，一時的な脳务血を招来 したり, 強いては，生体の防絜反底 をはるかに疼き急性死の原因となり 


\section{写 真 $\mathbf{C}_{3}$}

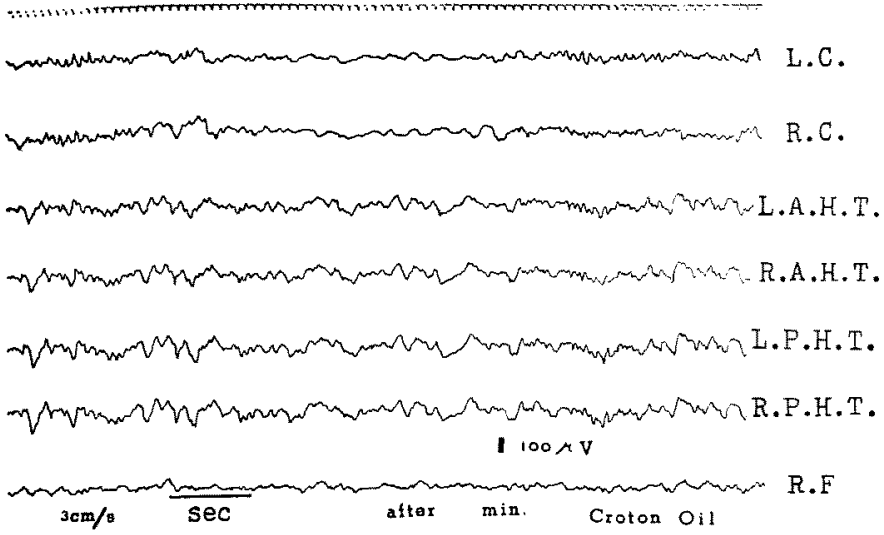

\section{写 真 $\mathbf{C}_{\boldsymbol{q}}$}

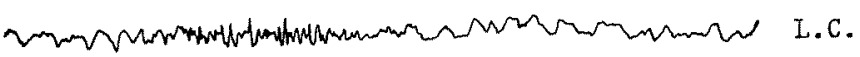

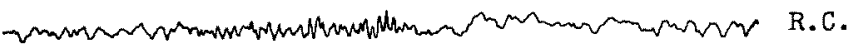

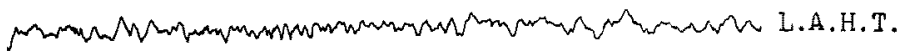

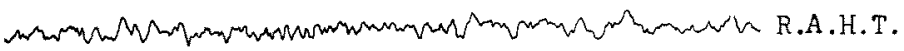

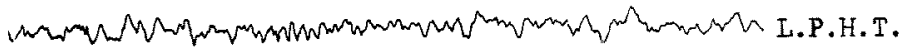

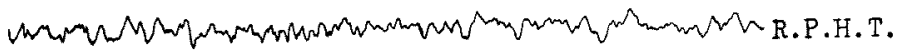
- $100 \mu \mathrm{V}$

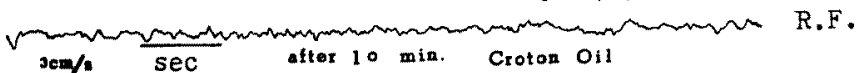

写 真 $\mathbf{D}_{\mathbf{1}}$

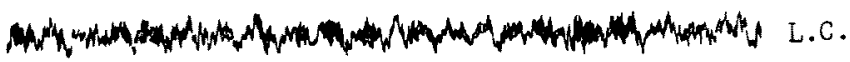
Fis

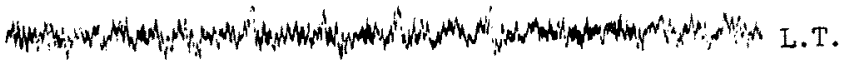

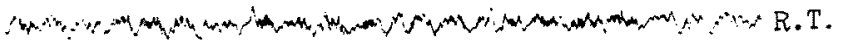

An 7t a

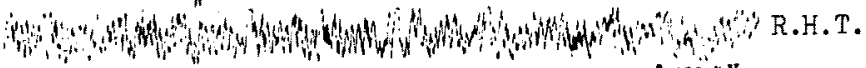

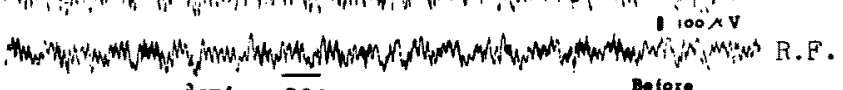
$\frac{3}{2} \mathrm{c}=\mathrm{y}: \mathrm{sec}$
得る可能性があると考えられてい る.

動物実験に沶いて最も適した刺激 物を探す目的で飯田 ${ }^{15) ~ は モ ル モ ッ ~}$ 卜を使用して口蓋部に種々の刺激物 即ち、オリーブ油, アドレナリン加

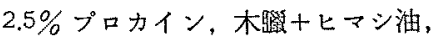
タルク $1 \%$ 醋酸塗液, シリコン油, クロトン油原液, 400 倍クロトン油, 交流電気刺激等を使用して, ショッ クの発現について詳細な研究を行つ ている.これによると上記刺激物の 中タルクとクロトン油原液が目的に かなつていると報告している.ショ ックを起した例に执いては，肺， 肝，筜等比出血性病変の著明なこと を病理 組織学的に 報告しているの で，著者も家鬼の扁桃を刺激する刺 激物にクロトン油原液を選び，その 量は実験上 $0.2 \sim 0.3 \mathrm{cc}$ 索適量と認 めた。深沢 ${ }^{16)}$ は飯田の研究を更に

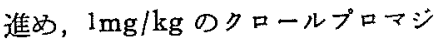
ンを使用してショック症状の阻止 に成功している，クロールプロマ ジンは山口与市, 土屋ら) の報告に よれば, 1951 年フランスの PhônePoulenc-Specia 製薬会社の製品で 構造式は次のごとくである。

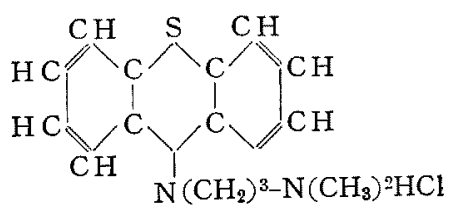

クロループロマシンの Reilly 現 象に対する作用としては，J. Reilly が発表した「侵裂に刘する自律神経 過度興奮に上万生体の非特異的反応 症候群」に対してある程度阻止的に 僖くと述べている. 又クロールブロ マジンは抗ショック作用を有し, 出 血性ショック及び外傷性ショックに 特異的予防効果を示儿, 内因的, 外

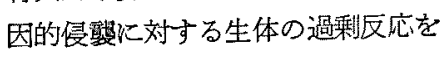


写真 $\mathbf{D}_{2}$

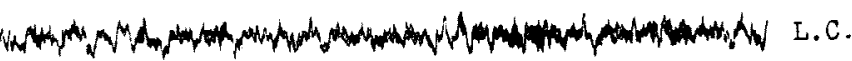

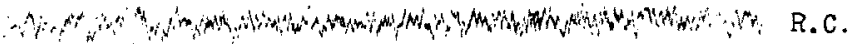

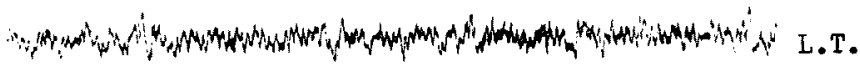

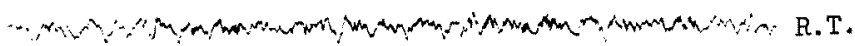

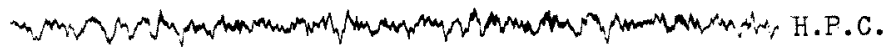

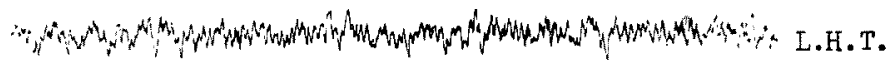

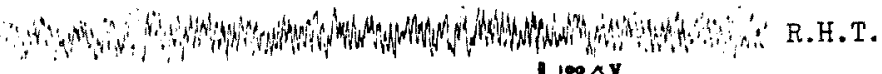

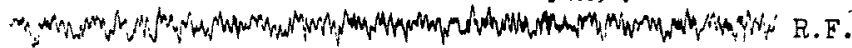

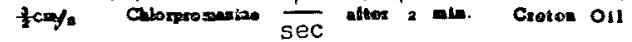

楥和し生体の無䭾なエネルギーを防ぎ得るとも報告され ている.クロールプロマジンを使用した実験は数多くあ るが Reilly 現象に有効と考党られる例を挙げると，安

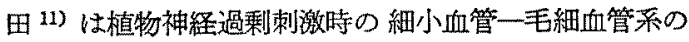
態度，その動態と透過性に抢ける下垂体副腎系の意議に 関する研究に和いて，左頸部迷走神経を露出して，電子 管装置による矩形波刺激で刺激し，腸間膜細小血管の透 過性の変化を追究している．この実験でクロールプロマ ジンを使用することにより毛細血管の透過性の元進が抑 制されている. 又山山口 ${ }^{19)}$ は口蓋帆過䣋刺激の末梢血管 に及活す影響とクロールプロマジンの阻止効果に関する 研究に括いて，刺激方法として電気刺激及び 化学刺激 （クロトン油）を用いてラッテの腸間膜の変化とをれを 阻止する目的でクロールプロマジンを使用して成功を和 さめている。

臨床上でもクルールプロマシンを使用してショック症

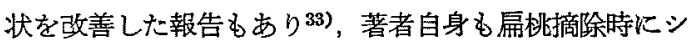
ヨック様定状に遭遇した際にクロールブロマシンを使用 てて一命を救い得た経験がある.そこで動物実験で生ず る異常脳波を抑える目的でクロールプロマシンを使用し た.

次に一側の自律神経の過剩刺激を行つた場合に刺激側 の遠湢部に病变がより強く生ずる場合之左右の有意差の 認められない実験例とが報告されている.刺激側の遠隔

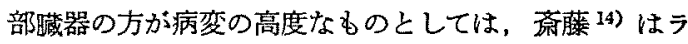
ッテの煩部過剩刺激により生ずる眼瞼部出血に関する研 究に招いて，クロトン油を頗部に注射して眼検出血を観 察し，その眼臉出血は注射側汇 $80 \%$ ，反対側にも50\% 生ずると報告している. 又鈴木20)はモルモットの眼窩
下神経に過剩刺激を与え，肺の出血性変 化の研究で, 刺激側の肺の充うつ血現象 のつよいことを報告している.

刺激側と反対側の有意差のない報告と して小林 ${ }^{10)}$ は植物神経起源による陠の 出血性病変の実験的研究に和いて, 䀦の 出血性病变は生体側の内部環境の桓常性 を維持せんとする調節反応の行きすぎの 一面の表わ扎であるして，モルモット を使用して左頸部迷走神経あるいは左顠 部交感神経を露出して電気刺激を試み た. 刃 400 倍クロトン油を使用して Sac jugulaire む施行した。この実験の結果 刺激群の肉眼的所見として 3 時間後俚 全例の両肺に限局性の新鮮な出血を認めている. 左右別 では多少刺激側に出血が著明の上万に認められたが反対 側との有意差はなかつた，病理学的所見からも毛細血管 は血球で充盈されていたが病変の著しい場合には肺胞暨 の毛細血管が極端に充盈し肺胞内も同様に新鮮な赤血球 で充满されて，いわゆる肺卒中の像を示していたと迎 ぺている．次にクロールプロマジンを 4 時間前に $1 \sim 2$ $\mathrm{mg} / \mathrm{kg}$ を皮下に注射した例に批いては肉眼的飞出血は 認められず，病理組織学的にも肺胞の含気性は多く，毛 細血管の充盈も汪とんどなく肺胞上皮も薄く出もと んどない例が多かつたと報告している。

以上の研究結果を綜合すると末梢自律神経を刺放する ことにより遠隔部の諸臓器に出血を主とする病変の表わ れること一刺激側の病变の強いこともあり左右差の性と んどないこともある. 左右差のあるなしにかかからす板 対側の遠隔の諸藏器汇病変を起すことからすれば，過利 刺激が自律神経に与えられた場合にそれが中枢を異常に 與奮させ中枢から両側性に過剩刺激が伝達され遠隔部の 諸葴器に病变を起すと考えられる。

自律神経の上行性の刺激伝導については色々問題の多 い点であり， Langley は求心性の線維を自律神経中に 認めず，Buchanan は一般内藏性求心性線維として特别 の線維を設けて説明するし，Ranson \& Clark は自律 神経系の項で内臓性求心性線維を述へて抢り，Evans は自律神経を交感系, 㓭交感系及び求心性の3つに分け て述へ，Fulton も自律神経の中に求心性の線稚を含ま しめるべきだと述へてている、いつれににしても自律神释は 求心性のものと遠心性のむのとの関係恃非常深いよう である、しかし，自律神経の過剩刺激が自律神軖線維を 


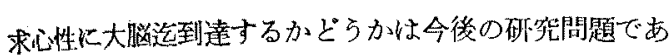

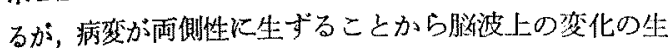
ずることを期待し脳の重要と考觉られる部位に電極を固 き単極誘導を行つた。

(1) 前視床下部及び徣視床下部に左在てれそれ2本の 電極を刺入した。視床下部は体温の調節，血王の恒常性 そついては延醓と共に重要な部位である。視床下部に電 極を刺入して高周波電流で刺潡すると末梢血管の抬張あ 总，甚しい発汗，心拍は和矢くなり，血压の下降も見 られると云ら䂺笵 ${ }^{23)}$ のなされている部位にて、ショッ クに閔係の深い部位と考えた。

(2) 網㥞体の刺激は動物の覚醒反応及び脳波の非動期

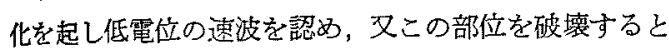

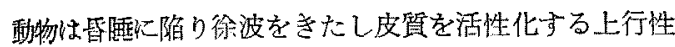
の働らきを持ら，Magoum はこの部位を網様賦活乔又 は上行性賦活系之呼んでいるここに左右一本づつ電極 咕入した。

(3) 皮貿以管炕網漛体等から刺激をらけている部位に て中枢絽由の刺激があるとすれば，皮質には大脳の各部 位加ら投影された脳波を得られると考え，弾力性に富ん

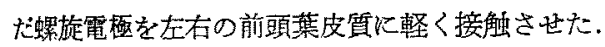

(1) その他視沫，海馬にも電極を刺入した例名ある.

涘頭鏡を使用して直視下に家鬼の口蓋府桃にクロトン 油原液 $(0.2 \sim 0.3 \mathrm{cc})$ を注入寸る際には脳波は非常に乱 れ判読不能となるが注射針を拢くとその直後から振俥数 の增加，振巾の減少と禁波の著明な出現を認めた。同様

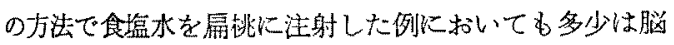
波上の変化は認められたが，クロトン油に比しては整微 であつた，又脽部皮下にクロトン油を注射した対照例で は絾波上の変化は㤠められなかつた。これは自律神経の

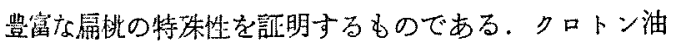

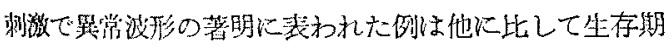
聞性短維し，最寻早いもので怯クロトン油注射後15分

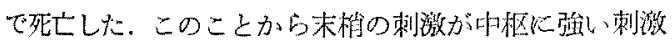

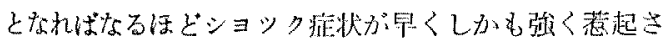

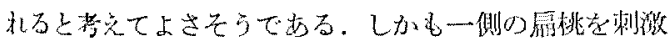

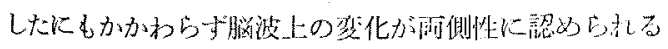

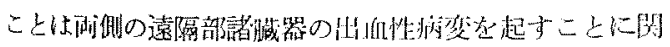

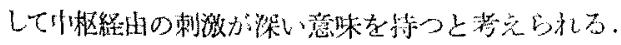

次にこれらの腌波の变化を阻止する目的で自律神程の

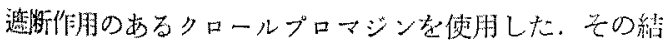

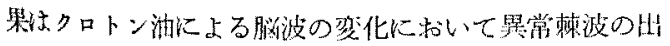

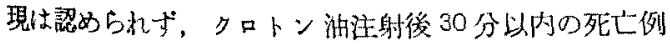

むなからた。これはタロールプロマジンが本梢自律神経

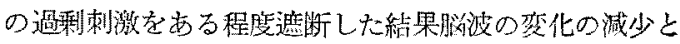
急州死を预しためのと考光ら机。。

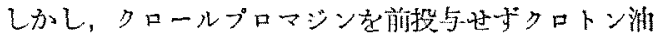
で訤没の变化を生じた家忍にクロールプロマジンの静脈

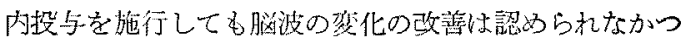
た。こ机は落床上ショック症状を起した患㨋にクロール ブロマジンを投与して好成績を得ている啹告や安田 の赫告の如く腸間膜の毛細近管の透過性九進時にクロー

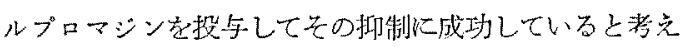

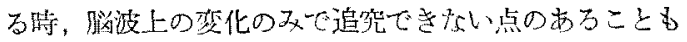
注意せねねぱならない。

いつれにしても自律神経の豊富な咽頭部殊に屚桃摘除

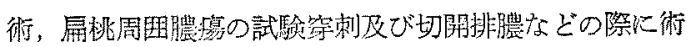

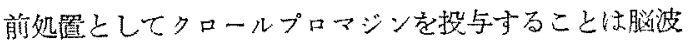
の变化から灭て有効な力法と考えられる.

\section{$\mathbf{E}$ : 結 論}

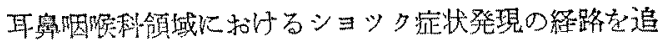

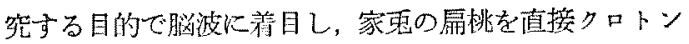
油で刺激し，脳波上の谓明な変化を認めた。遠原諸臟器 の出血性病变は中枢経由の過剩刺激と関係の深いことを 証明した、又クロールプロマジンを使用して㨫波の変化 の抑制とそれに伴う急性死の阻止を確めた。

1）家息の脆桃を刺激してその時の脳波の著明な变化

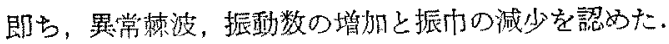

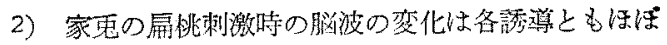
同時であり誘算部位に上る左右善はほとんど認められな かつた。

3）家雭の腹部にクロトン油を注射したるのでは脪波 の变化は認められなからた。

4) クロールプロマジンを前処置として使用すること

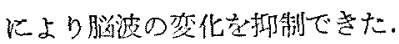

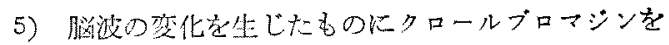

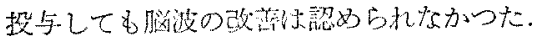

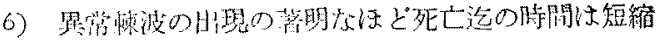
它札た。

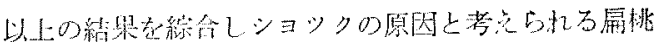

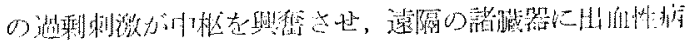

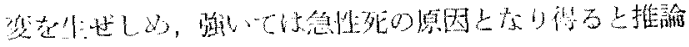
した。

\section{主要文献}

1) J. Reilly: Comp. Rend. Soc. Biol, Tom. 148: $1374,1954.2$ 2) H. Selye: The story of adapta- 


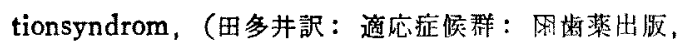
昭和27年)。 3) H. Selye: The textbook of endocrinology（田多井訳：七り工新内分泌学，医藏薬出 帊). 4) 山口与市: 噔応医学, 第 33 巻, 第 5 号, 213、昭和 31 年. 5) 山口与市, 他: 最新医学, 第 10 巻, 第10号, 366, 昭和 30 年, 6) 山口与市, 他: 日本䠛床，第 18 缶，第 3 号，106，昭和 35 年.7) 鈴 木安恒，他：耳略咽喉科，第 30 巻，第 3 号, 153, 昭 和 33 年. 8) 田方溥一：鼠新医学、第 9 巻, 第11号, 昭和 30 年。9) 秋庭忠義：庭応医学，第36卷，第 8 号, 881，昭和 34 年。10）小林吉哉：磨応医学，第 37 巻，第 2 号， 257 , 昭和 35 年 11) 安田三沵：度 応医学，第 37 巻，第 10 号，昭和 35 年。12) 山口麗： 日兮奥，第 64 巻，第 2 号，278,1961 年. 13) 坂口正

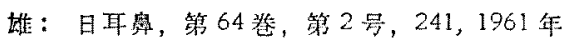
新藤英子：日耳鼠，第 68 巻，第 10 号，2214，1960年 15）领田稳：耳鼻咽喉科，第 30 巻，第 3 号，158，炤 和 33 年. 16) 深沢久夫：耳舁咽喉科，第 30 巻，第

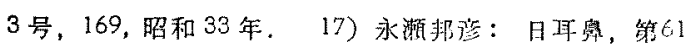
巻，第9号，1480，昭和 33 年。18）大䱚交朗：日耳 鼻，第 63 巻，第 1 号，56，昭和 35 年。19）井上寿樹： 日耳鼻，第 63 巻，第 4 号，617，昭和 35 年. 20) 鈴木

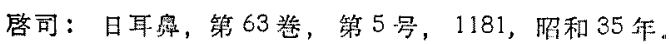
21) 高崎晃: 日耳析, 第 63 替, 第 5 号, 1250, 昭和 35 年 22) 鉿木安恒，士屋：日仏医学、第 3 巻，第 4

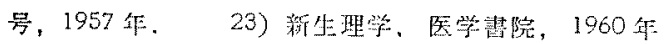

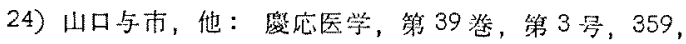

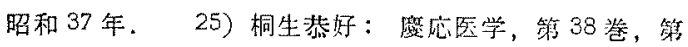
5 号，413，昭和 36 年. 26) Yoichi Yamaguchi, $M$.
Tsuchiya, T. Akiba, K. Kobayashi, K. Shiraishi H. Nozaki: Keio Journal of Medicine Vol. 9. No. 2, 91, 1960. 27) Yasunobu Suzuki,: Keio Journal of Medicine Vol. 9, No. 3, 211, $1960 . \quad 28)$ Yasu. nobu Suzuki, E. Yamaguchi, M. Iida, I. Miyabe, M. Tsuchiya, M. Ogawa: Keio Journal of Medicine Vol. 9, No. 2, 121, $1960 . \quad 29)$ Speransky: A basis for the theory of medicine; Intern. Publ.-Co 1947. 30) H. Laborit: Réaction Organique a lágression et choc. 1954. Masson et Cie. (侵裂比奶 寸る生体反底とショック，山口与市他訳)。 Evans, C.L.: Principles of Human Physiology 1956. 32) Fulton, J.F.: A Textbook of Physiology 7th ed. 1955. 33) 11口-与市, 白石幸治郎, 土屋雅春，秋

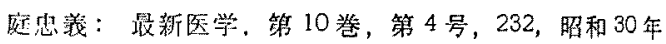
4 月。

和老終るに望及御愁䈍なる御指導上御校閲の

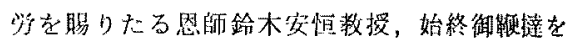

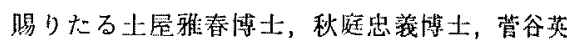
一路士，桐生恭好博士，御協力を慒しまず研究 の場を与えて下さつた日発病院並びに院長白石 幸治毁慺士，東京第二国立病院生理科本国正節 㩭士に感謝致します。

本諭交の要旨は眧和 38 作 4 月 3 日第 64 同日

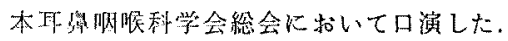

(原稿到着 $=$ 昭和 38.9 .3 日) 